\title{
PENGARUH KEPUASAN KERJA TERHADAP KINERJA KARYAWAN
}

\author{
Nuraini Eka Sandra (17002097) \\ Psikologi manajemen - Administrasi pendidikan \\ Email : nurainiekasandra99154@gmail.com
}

\begin{abstract}
Abstrak
Perusahaan yang menganggap SDM sebagai salah satu aset perusahaan, tentu hal ini mendorong para manajer perusahaan untuk berusaha semaksimal mungkin mengelola SDM Secara umum banyak sekali faktor-faktor yang dapat dan sering mempengaruhi kinerja karyawan, dan salah satu contohnya adalah faktor kepuasn kerja. Kepuasan kerja merupakan sesuatu hal yang diharapkan oleh setiap karyawan di perusahaan. Biasanya, karyawan yang merasa puas dapat mengarahkan karyawan pada kondisi diri yang positif seperti merasa semangat dan giat dalam bekerja.

Mengingat pentingnya kepuasan kerja karyawan, maka kepuasan kerja merupakan salah satu faktor yang perlu mendapat perhatian pimpinan perusahaan. Dalam kenyataannya banyak pimpinan perusahaan belum sepenuhnya menyadari pengaruh dan arti penting dari kepuasan kerja. Bahkan perusahaan masih menganggap SDM sebagai biaya (cost) bagi perusahaan, sehingga pengelolaan SDM yang ada belum maksimal dilakukan, Jika kepuasan kerja tidak maksimal akan berpengaruh pada pencapaian kinerja karyawan yang juga kurang maksimal
\end{abstract}

Kata kunci : kepuasan kerja, 


\section{A. PENDAHULUAN}

1. Latar belakang

Secanggih apa pun teknologi yang ada dan digunakan oleh suatu perusahaan, sebesar apa pun modal usaha yang diperlukan, namun keberadaan SDM tetap menjadi prioritas utama, karena SDM merupakan pelaku dan faktor penentu lancarnya sebuah organisasi.

Mengingat pentingnya kepuasan kerja karyawan, maka kepuasan kerja merupakan salah satu faktor yang perlu mendapat perhatian pimpinan perusahaan. Dalam kenyataannya banyak pimpinan perusahaan belum sepenuhnya menyadari pengaruh dan arti penting dari kepuasan kerja. Bahkan perusahaan masih menganggap SDM sebagai biaya (cost) bagi perusahaan, sehingga pengelolaan SDM yang ada belum maksimal dilakukan.

Pengelolaan SDM yang kurang maksimal dapat mengakibatkan tingkat kepuasan kerja juga kurang maksimal. Jika kepuasan kerja tidak maksimal akan berpengaruh pada pencapaian kinerja karyawan yang juga kurang maksimal.

\section{Rumusan masalah}

Dari latar belakang diatas sehingga menimbulkan masaah yaitu apa yang dimaksud denga kepuasan kerja ? bagaimana pengaruh kepuasan kerja terhadap kinerja karyawan

\section{Tujuan penulisan}

Untuk menjawab pertanyaan tersebut di atas, selanjutnya dalam artikel ini akan dipaparkan secara rinci tentang definisi kepuasan kerja, faktor-faktor dalam kepuasan kerja, dimensi pengukuran kepuasan kerja, dan pengaruh kepuasan kerja terhadap kinerja karyawan. 


\section{A. DEFINISI KEPUASAN KERJA}

kepuasan kerja adalah keadaan emosi yang senang atau emosi positif yang berasal dari penilaian pekerjaan atau pengalaman kerja seseorang. Kepuasan kerja adalah hasil dari persepsi karyawan mengenai seberapa baik pekerjaan mereka memberikan hal yang dinilai penting. (Bodroastuti \& Suprihatiningrum, 2012)

Definisi penelitian yang paling banyak digunakan tentang kepuasan kerja adalah oleh Locke (1976), ". . . keadaan emosional yang menyenangkan atau positif yang dihasilkan dari penilaian pengalaman kerja seseorang atau pekerjaan "(p. 1304). Definisi implisit dalam definisi Locke adalah pentingnya ketidaksempurnaan, atau perasaan, dan kognisi, atau pemikiran. Ketika kita berpikir, kita memiliki perasaan tentang apa yang kita pikirkan. Sebaliknya, ketika kita memiliki perasaan, kita memikirkan apa yang kita rasakan. Kognisi dan cacat dengan demikian terkait erat, dalam psikologi-kita dan bahkan dalam biologi kita. Jadi, ketika mengevaluasi pekerjaan kita, seperti ketika kita menilai segala sesuatu yang penting bagi kita, baik pemikiran maupun perasaan terlibat.

\section{B. FAKTOR-FAKTOR DALAM KEPUASAN KERJA}

Kepuasan setiap individu karyawan memiliki tingkatan yang berbeda, karena faktor-faktor yang mempengaruhi pun juga dapat berbeda-beda. Misalnya ada individu yang merasa puas karena besaran gaji, namun ada individu lain merasa puas karena faktor lingkungan kerjanya.(Saari \& Judge, 2004)

Faktor yang memberikan kepuasan kerja menurut (Locke, 1976), adalah sebagai berikut:

1. Faktor individual, meliputi umur, kesehatan, watak dan harapan;

2. Faktor sosial, meliputi hubungan kekeluargaan, pandangan masyarakat, kesempatan berkreasi, kegiatan perserikatan pekerja, kebebasan berpolitik, dan hubungan kemasyarakatan

3. Faktor utama dalam pekerjaan, meliputi upah, pengawasan, ketentraman kerja, kondisi kerja, dan kesempatan untuk maju.

Selain itu juga penghargaan terhadap kecakapan, hubungan sosial di dalam pekerjaan, ketepatan dalam menyelesaikan konflik antar manusia, perasaan diperlakukan adil baik yang menyangkut pribadi maupun tugas. 
Selanjutnya pendapat (Weiss \& Merlo, 2015) tentang faktor-faktor yang mempengaruhi kepuasan kerja sebagai berikut:

1. Kesempatan untuk maju.

Dalam hal ini ada tidaknya kesempatan untuk memperoleh pengalaman dan peningkatan kemampuan selama kerja

2. Keamanan kerja.

Faktor ini sering disebut sebagai penunjang kepuasan kerja, baik bagi karyawan pria maupun wanita. Keadaan yang aman sangat mempengaruhi perasaan karyawan selama kerja

3. Gaji

Gaji lebih banyak menyebabkan ketidakpuasan, dan jarang orang mengekspresikan kepuasan kerjanya dengan sejumlah uang yang diperolehnya

4. Perusahaan dan manajemen.

Perusahaan dan manajemen yang baik adalah yang mampu memberikan situasi dan kondisi kerja yang stabil. Faktor ini yang menentukan kepuasan kerja karyawan

5. Pengawasan (Supervise).

Bagi karyawan, supervisor dianggap sebagai figur ayah dan sekaligus atasannya. Supervisi yang buruk dapat berakibat absensi dan turn over;

6. Faktor Instrinsik dari Pekerjaan.

Atribut yang ada pada pekerjaan mensyaratkan ketrampilan tertentu. Sukar dan mudahnya serta kebanggaan akan tugas akan meningkatkan atau mengurangi kepuasan

7. Kondisi kerja.

Termasuk di sini adalah kondisi tempat, ventilasi, penyinaran, kantin dan tempat parkir

8. Aspek sosial dalam pekerjaan.

Merupakan salah satu sikap yang sulit digambarkan tetapi dipandang sebagai faktor yang menunjang puas atau tidak puas dalam kerja;

9. Komunikasi.

Komunikasi yang lancar antar karyawan dengan pihak manajemen banyak dipakai alasan untuk menyukai jabatannya. Dalam hal ini adanya kesediaan pihak atasan untuk mau 
mendengar, memahami dan mengakui pendapat ataupun prestasi karyawannya sangat berperan dalam menimbulkan rasa puas terhadap kerja;

10. Fasilitas.

Fasilitas rumah sakit, cuti, dana pensiun, atau perumahan merupakan standar suatu jabatan dan apabila dapat dipenuhi akan menimbulkan rasa puas.

Untuk memberikan kepuasan kerja juga diperlukan komunikasi yang efektif yaitu hubungan antar manusia. hubungan antar manusia adalah kegiatan komunikasi persuasif yang bukan hanya sekedar relasi atau hubungan saja melainkan suatu aktivitas dan suatu kegiatan untuk mengembangkan rasa bahagia dan rasa puas, serta kegiatan untuk meningkatkan dan mengembangka lebih produktif dan memuaskan. Komunikasi persuasif yang dimaksud di sini adalah komunikasi yang bersifat membujuk agar tercipta hubungan yang baik. (Ermita, 2012)

\section{TUJUAN PENGUKURAN KEPUASAN KERJA}

Seperti dalam penjelasan sebelumnya bahwa kepuasan kerja karyawan dapat dilihat dan nampak dari sikap positif karyawan. kepuasan kerja perlu dipantau dengan cara mengukur tingkat kepuasan kerja karyawan.(Weiss \& Merlo, 2015)

Tujuan pengukuran kepuasan kerja bagi para karyawan adalah :

1. Mengidentifikasi kepuasan karyawan secara keseluruhan, termasuk kaitannya dengan tingkat urutan prioritasnya (urutan faktor atau atribut tolok ukur kepuasan yang dianggap penting bagi karyawan). Prioritas yang dimaksud dapat berbeda antara para karyawan dari berbagai bidang dalam organisasi yang sama dan antara organisasi yang satu dengan yang lainnya.

2. Mengetahui persepsi setiap karyawan terhadap organisasi atau perusahaan. Sampai seberapa dekat persepsi tersebut sesuai dengan harapan mereka dan bagaimana perbandingannya dengan karyawan lain.

3. Mengetahui atribut-atribut mana yang termasuk dalam kategori kritis (critical perfoment attributes) yang berpengaruh secara signifikan terhadap kepuasan karyawan. Atribut yang bersifat kritis tersebut merupakan prioritas untuk diadakannya peningkatan kepuasan karyawan. 
4. Apabila memungkinkan, perusahaan atau instansi dapat membandingkannya dengan indeks milik perusahaan atau instansi saingan atau yang lainnya

\section{DIMENSI PENGUKURAN KEPUASAN KERJA}

Dimensi pengukuran kepuasan kerja menurut (Tietjen \& Myers, 1998) menyebutkan kepuasan kerja adalah sejauh mana individu merasakan secara positif atau negatif berbagai macam factor atau dimensi dari tugas-tugas dalam pekerjaannya. Kepuasan kerja berkaitan dengan beberapa aspek, yaitu :

1. Gaji, yaitu jumlah bayaran yang diterima seseorang sebagai akibat dari pelaksanaan kerja apakah sesuai dengan kebutuhan dan dirasakan adil.

2. Pekerjaan itu sendiri, yaitu isi pekerjaan yang dilakukan seseorang apakah memiliki elemen yang memuaskan.

3. Rekan kerja, yaitu teman-teman kepada siapa seseorang senantiasa berinteraksi dalam pelaksanaan pekerjaan. Seseorang dapat merasakan rekan kerjanya sangat menyenangkan atau tidak menyenangkan.

4. Atasan, yaitu seseorang yang senantiasa memberi perintah atau petunjuk dalam pelaksanaan kerja. Cara-cara atasan dapat tidak menyenangkan bagi seseorang atau menyenangkan dan hal ini dapat mempengaruhi kepuasan kerja.

Hasil penelitian menunjukkan bahwa gaya kepemimpinan atasan berkontribusi terhadap kinerja pegawai sebesar 50,8\%. Hasil penelitian ini didukung oleh pendapat Thoha (1995) bahwa gaya kepemimpinan adalah cara yang dipergunakan pimpinan dalam mempengaruhi pengikutnya. Artinya, guna mencapai kinerja guru yang baik, maka kepala sekolah harus mampu mempengaruhi guru agar mau melaksanakan tugasnya dengan baik. (Ermita, 2019)

5. Promosi, yaitu kemungkinan seseorang dapat berkembang melalui kenaikan jabatan. Seseorang dapat merasakan adanya kemungkinan yang besar untuk naik jabatan atau tidak, proses kenaikan jabatan kurang terbuka atau terbuka. Ini juga dapat mempengaruhi tingkat kepuasan kerja seseorang.

6. Lingkungan kerja, yaitu lingkungan fisik dan psikologis. 


\section{E. PENGARUH KEPUASAN KERJA TERHADAP KINERJA}

Pemenuhan kebutuhan kepuasan kerja bagi karyawan perlu mendapat perhatian dan harus dilakukan oleh manajemen perusahaan. Hal ini untuk menghindari dampak-dampak yang tidak diinginkan yang dapat merugikan karyawan yang pada akhirnya dapat merugikan perusahaan. Selain itu faktor kepuasan kerja juga dapat mempengaruhi tingkatan hasil pencapaian kinerja masing-masing individu atau karyawan.("Pengaruh Motivasi Kerja, Kepemimpinan dan Budaya Organisasi Terhadap Kepuasan Kerja Karyawan serta Dampaknya pada Kinerja Perusahaan (Studi kasus pada PT. Pei Hai International Wiratama Indonesia),” 2008) 


\section{DAFTAR PUSTAKA}

Bodroastuti, H., \& Suprihatiningrum, T. (2012). Faktor - Faktor Yang Mempengaruhi Prestasi Kerja ( Studi Pada Karyawan Kantor Kementrian Agama Provinsi Jawa Tengah ). Jurnal Kajian Akuntansi Dan Bisnis.

Ermita. (2019). Kontribusi Gaya Kepemimpinan Kepala Sekolah Dan Motivasi Kerja Terhadap Kinerja Guru di Sekolah Menengah Atas (SMAN) Kecamatan Koto Tangah Kota Padang. HIJRI,Jurnal Manajemen Pendidikan Dan Keislaman, 8(1), 107-123. https://doi.org/10.1017/CBO9781107415324.004

Ermita, E. (2012). Hubungan Antar Manusia dan Semangat Kerja Pegawai. PEDAGOGI,Jurnal Ilmiah Ilmu Pendidikan, 12(2), 70-81.

Locke, E. A. (1976). The nature and causes of job satisfaction. In Handbook of Industrial and Organizational Psychology.

Pengaruh Motivasi Kerja, Kepemimpinan dan Budaya Organisasi Terhadap Kepuasan Kerja Karyawan serta Dampaknya pada Kinerja Perusahaan (Studi kasus pada PT. Pei Hai International Wiratama Indonesia). (2008). Jurnal Manajemen Dan Kewirausahaan. https://doi.org/10.9744/jmk.10.2.pp.124-135

Saari, L. M., \& Judge, T. A. (2004). Employee attitudes and job satisfaction. Human Resource Management. https://doi.org/10.1002/hrm.20032

Tietjen, M. A., \& Myers, R. M. (1998). Motivation and job satisfaction. Management Decision. https://doi.org/10.1108/00251749810211027

Weiss, H. M., \& Merlo, K. L. (2015). Job Satisfaction. In International Encyclopedia of the Social \& Behavioral Sciences: Second Edition. https://doi.org/10.1016/B978-0-08-097086$8.22029-1$ 